Cohen, A. S., Calkins, E., and Mullinax, P. F. (1962). Archives of Internal Medicine, 110, 569.

Dick, G. F., and Leiter, L. (1935). Transactions of the Association of American Physicians, 50, 135.

Dick, G. F., and Leiter, L. (1937). Transactions of the Association of American Physicians, 52, 246. Dick, G. F., and Leiter, L. (1941). American fournal of Pathology,

Gardner, D. L. (1962). Annals of the Rheumatic Diseases, 21, 298.

Ogawa, M., Clendenning, W. E., and Baughman, R. D. (1969). Archives of Dermatology, 99. In press.

Rask-Nielsen, R., Christensen, H. E., and Clausen, J. (1960). fournal of the National Cancer Institute, 25, 315. Roe, D. A. (1958). Annals of the New York Academy of Sciences, 73,

Shelley, W. B. (1964). fournal of the American Medical Association, 189, 985.

Shelley, W. B. (1967). fournal of the American Medical Association, 201,1009 .

Skog, E., and Linder, O. (1965). Acta Dermato-venereologica, 45, 461. Sönnichsen, N., Apostoloff, G., and Nebe, H. (1965). Dermatologische Wochenschrift, 151, 1423.

Teilum, G. (1964). Acta Pathologica et Microbiologica Scandinavica, $61,21$.

Transactions of St. Fohn's Hospital Dermatological Society, 1965, 51, 106.

\title{
Boric Acid Preservation of Urine Samples
}

\author{
I. A. PORTER,* M.D., M.C.PATH. ; J. BRODIE, $\dagger$ M.D., D.P.H., F.C.PATH.
}

British Medical fournal, 1969, 2, 353-355

\begin{abstract}
Summary : Comparison of the results of bacteriological $\checkmark$ culture and microscopic examination of urine samples transported over a distance by the dip-inoculum transport medium, ice-box, and boric acid preservation with "natural" urine specimens showed that the last, in a final concentration of $1.8 \%$, gives satisfactory preservation.
\end{abstract}

\section{Introduction}

Urine is a good culture medium. Delay in delivery to the laboratory may lead to an increase in bacterial content from an initial number of no significance to a total which may be construed as significant. The midstream specimen, promptly delivered, is acceptable for bacteriological examination provided strict care is taken both in the preparation of the patient and in the collection of the sample. The urine must be delivered to the laboratory within one hour of passing. Refrigeration of the specimen for up to 48 hours before delivery is also acceptable.

It is impossible to meet these requirements when the urine comes from a distance and must be sent, for example, by post. Certain procedures to obviate such difficulties have been evolved-for example, the dip-inoculum transport medium outfit (D.I.T.M.) of Mackey and Sandys (1965) and the dipslide technique of Naylor and Guttmann (1967). Both of these methods allow the bacterial count per ml. of urine to be calculated. The significance of the count is interpreted on the basis of the recommendations of Kass (1956), so that a bacterial content of over 100,000 organisms per ml. is of significance, between 10,000 and 100,000 is of doubtful significance, and under 10,000 is of no significance. Counts within each range given above are abbreviated to $S, D S$, and NS respectively.

The Laboratory, City Hospital, Aberdeen, receives around 140,000 specimens annually, of which some 17,000 are urines. The majority of specimens cannot be delivered to the laboratory within the optimal time because most users of the service are outside the City of Aberdeen itself. The catchment area comprises Kincardineshire, Aberdeenshire, Banffshire, Moray, and Nairn, and includes the Orkney and Shetland groups of islands. There is a brisk postal service between the laboratory

\section{* Consultant Bacteriologist.}

+ Consultant-in-Charge.

The Laboratory, City Hospital, Aberdeen. and its users. The majority of specimens arrive within 24 hours of posting, but delays of two to three days are not uncommon, especially if specimens are taken and dispatched at week-ends. Special provisions are made to minimize deterioration of some types of specimens while in transit-for example, serum-coated swab outfits, use of Stuart's transport medium, etc. A urine sample outfit suitable for all users of the laboratory has been difficult to find. Trials of both the dip-inoculum outfit and ice-box transport have been undertaken.

A new outfit using boric acid as a preservative has been evolved and the comparative results are given and discussed. Results with this outfit have been so encouraging that it is now being issued in the region for all urine samples requiring bacteriological examinations.

\section{Procedures and Results}

\section{D.I.T.M. Compared with "Natural " Urine Specimen}

With the co-operation of the New Gilbert Bain Hospital, Lerwick, Shetland, arrangements were made to send 100 urines. From each midstream specimen collected, $1 \mathrm{fl}$. oz. $(28 \mathrm{ml}$.) was dispatched in a sterile universal container. A D.I.T.M. sample was also taken from the same urine at the same time. Both were posted in the same envelope to the laboratory in Aberdeen. Of the specimens, 38 were at least two days old on receipt.

The D.I.T.M. was incubated at $37^{\circ}$ C. for 24 hours. The colony count was then taken and the number of organisms per ml. calculated. The " natural" urine on receipt was shaken and sampled with a $4 \mathrm{~mm}$. loop. The loopful was spread everly on culture media and colony counts were made after 24 hours at $37^{\circ} \mathrm{C}$. The average of the counts multiplied by 100 gave the number of organisms per $\mathrm{ml}$.

If it is accepted that the D.I.T.M. result is more accurate than that obtained from the natural urine specimen in these circumstances, then the results compare as set forth in Table I, which shows that 18 of the 100 natural urines gave results which did not correspond with the D.I.T.M. estimations. Of these 18 , the number showing more organisms than the D.I.T.M. parallel samples was 13. Of the five urines with lower counts than the corresponding D.I.T.M. samples, three contained Proteus spp., one a strain of Escherichia coli, and the fifth a coagulase-negative staphylococcus. 
TABLE I.-D.I.T.M. Results Compared with Natural Urine Specimen Findings

\begin{tabular}{|c|c|c|c|c|c|c|c|c|c|}
\hline D.I.T.M. & & & & Total & Natural Urin & & & & Total \\
\hline s &.. & .. & .. & 29 & $\begin{array}{l}\text { S } \\
\text { DS }\end{array}$ & $\because$. & $\because$. & $\therefore$ & 26 \\
\hline DS &.. &.. & .. & 15 & $\begin{array}{l}\text { DS } \\
\text { SS }\end{array}$ & $\begin{array}{l}. \\
\because .\end{array}$ & $\begin{array}{l}. . \\
\because .\end{array}$ & $\begin{array}{l}. \\
\because .\end{array}$ & $\begin{array}{l}5 \\
8 \\
2\end{array}$ \\
\hline NS &.. & $\ldots$ & .. & 56 & $\begin{array}{l}\text { NS } \\
\text { S } \\
\text { DS }\end{array}$ & $\begin{array}{l}. \\
\because .\end{array}$ & $\begin{array}{l}. . \\
\because .\end{array}$ & $\begin{array}{l}. \\
\because\end{array}$ & $\begin{array}{r}51 \\
3 \\
2\end{array}$ \\
\hline Total &.. &.. & .. & 100 & Total &.. & .. & .. & 100 \\
\hline
\end{tabular}

* Proteus $\mathrm{sp}$. in all three specimens.

$>100,000$ organisms per $\mathrm{ml} .=$ significant

DS indicates bacterial count $>10,000$ but $<100,000$ organisms per ml. = doubtfully significant.

$\mathrm{NS}$ indicates bacterial count $<10,000$ organisms per ml. = not significant.

\section{Comparisons of D.I.T.M., Urine with 1.8\% Boric Acid, and Natural Urine Specimens}

The new urine outfit with preservative was now added to the trial, so that each midstream specimen of urine had three samples taken-namely, the natural urine, the D.I.T.M. sample, and the sample with boric acid. All three were packed in the same envelope and dispatched by post.

The new outfit consisted simply of a 1-fl. oz. (28-ml.) universal container to which $0.5 \mathrm{~g}$. of powdered boric acid had been added before issue from the laboratory. The preserved urines were plated with the 4-mm. measured loop.

Again this trial was done with the co-operation of the New Gilbert Bain Hospital, Shetland. Table II gives the results of 40 urines so examined and shows that the boric acid outfit gave full agreement with the D.I.T.M. in 38 of the 40 urines, whereas only 29 of the natural urines showed agreement.

TABLE II.-D.I.T.M. Results Compared with Boric Acid Outfit and

\begin{tabular}{|c|c|c|c|c|c|c|c|c|}
\hline D.I.T.M. & & Total & $\begin{array}{l}\text { Boric Acid } \\
\text { Outfit }\end{array}$ & & Total & $\begin{array}{c}\text { Natural } \\
\text { Urine }\end{array}$ & & Total \\
\hline$s$ & .. & 7 & $\begin{array}{l}\text { S } \\
\text { DS }\end{array}$ & .. & $\begin{array}{l}6 \\
1^{*}\end{array}$ & $s$ &.. & 7 \\
\hline DS & .. & 3 & $\begin{array}{l}\text { DS } \\
\text { NS }\end{array}$ & $\therefore$ & $\begin{array}{l}2 \\
1 \dagger \\
\end{array}$ & $\begin{array}{l}\text { DS } \\
\text { St }\end{array}$ &.. & $\begin{array}{l}1 \\
2 \\
\end{array}$ \\
\hline $\mathrm{NS}$ & .. & 30 & NS & .. & 30 & $\begin{array}{l}\text { NS } \\
\text { DS } \\
\text { S }\end{array}$ & $\begin{array}{l}. \\
\because .\end{array}$ & $\begin{array}{r}21 \\
4 \\
5\end{array}$ \\
\hline Total & .. & 40 & Total & . & 40 & Total & .. & 40 \\
\hline
\end{tabular}

* Proteus sp. in all three outfits. † Klebsiella sp. in all three outfits.

After the initial examinations the natural urine samples and the boric acid preserved urines were left at room temperature (about $18^{\circ}$ C.) for three days and again examined. These delayed examination results are given in Table III.

Comparison of the boric acid outfit results in Tables II and III show that two of the $S$ results in Table II had become DS in Table III. Scrutiny of the detailed results from which the tables were compiled showed that both urines contained Proteus species. Of the natural urine results 14 were $S$ on receipt and 28 were $\mathrm{S}$ after sitting three days at room temperature.

TABLE III.-Boric Acid Outfit and Natural Urine Findings After Three

\begin{tabular}{|c|c|c|c|c|c|c|c|c|c|}
\hline $\begin{array}{l}\text { Bori: : Acid } \\
\text { Ciutfit }\end{array}$ & & & & Total & $\begin{array}{c}\text { Natural } \\
\text { Urine }\end{array}$ & & & & Total \\
\hline $\mathrm{s}$ & . & .. & .. & 4 & $s$ & .. & $\ldots$ & .. & 4 \\
\hline $\mathrm{DS}$ & .. & .. & . & 5 & $\begin{array}{l}\text { DS } \\
\text { NS } \\
\text { S }\end{array}$ & $\begin{array}{l}\because \\
\because \\
.\end{array}$ & $\begin{array}{l}. \\
\because .\end{array}$ & $\begin{array}{l}. \\
\because \\
.\end{array}$ & $\begin{array}{l}1 \\
1 \\
3\end{array}$ \\
\hline NS & .. & .. & .. & 31 & $\begin{array}{l}\text { NS } \\
\text { DS } \\
\text { S }\end{array}$ & $\ddot{.}$ & $\because$. & $\ddot{.}$ & $\begin{array}{r}9 \\
1 \\
21 \\
\end{array}$ \\
\hline Total & .. &.. & .. & 40 & Total &.. &.. & .. & 40 \\
\hline
\end{tabular}

\section{Comparisons of Ice-box, Boric Acid Preserved, and Natural Urine Specimens}

With the co-operation of the Balfour Hospital, Kirkwall, Orkney, three samples each of 65 midstream specimens of urines were taken. The 1-fl. oz. (28-ml.) samples in universal containers were placed in an insulated box containing ice in a plastic compartment and dispatched by the regular B.E.A. air service to Aberdeen. The boric acid outfits with the natural samples of the same urines were paired, packed, and dispatched, each pair in the same envelope, by post. Special arrangements were made to collect the ice-box samples on arrival in Aberdeen and to have these examined immediately on receipt. The majority of ice-box urines were about six hours in transit between Kirkwall and the laboratory, but the postal specimens suffered variable delays. The checks made on the temperatures of the ice-box on receipt showed a range of from $9^{\circ}$ to $15^{\circ} \mathrm{C}$., which would not indicate optimal cooling while in transit. The results are given in Table IV.

TABLE IV.-Boric Acid Outfits Compared with Ice-box Urines and Natural Urine Specimens Examined on Receipt

\begin{tabular}{|c|c|c|c|c|c|c|c|c|}
\hline $\begin{array}{l}\text { Boric: Acid } \\
\text { Outfit }\end{array}$ & & Total & $\begin{array}{c}\text { Ice-box } \\
\text { Urine }\end{array}$ & & Total & $\begin{array}{c}\text { Natural } \\
\text { Urine }\end{array}$ & & Total \\
\hline$S$ & $\ldots$ & 10 & $S$ & $\ldots$ & 10 & $\mathrm{~S}$ & $\ldots$ & 10 \\
\hline DS & . & 6 & $\begin{array}{l}\text { DS } \\
\text { NS } \\
\text { S }\end{array}$ & $\ldots$ & $\begin{array}{l}4 \\
1 \\
1 *\end{array}$ & $\begin{array}{l}\text { DS } \\
\text { NS } \\
\text { S }\end{array}$ & $\begin{array}{l}\ldots \\
\cdots\end{array}$ & $\begin{array}{l}2 \\
0 \\
4\end{array}$ \\
\hline NS & . & 49 & $\begin{array}{l}\text { NS } \\
\text { DS } \\
\text { S }\end{array}$ & $\begin{array}{l}\ldots \\
\ldots\end{array}$ & $\begin{array}{c}48 \\
1^{*} \\
0\end{array}$ & $\begin{array}{l}\text { NS } \\
\text { DS } \\
\text { S }\end{array}$ & $\begin{array}{l}\cdots \\
\cdots\end{array}$ & $\begin{array}{r}28 \\
8 \\
13\end{array}$ \\
\hline Total & $\ldots$ & 65 & Total & $\ldots$ & 65 & Total & $\ldots$ & 65 \\
\hline
\end{tabular}

The boric acid outfits and the ice-box transported urines show a remarkable similarity of findings. When delay in transit of the ice-box does occur, misleading results may be obtained (Table IV). Of the 65 urines sampled these three ways, 49 gave NS results with the boric acid outfit and 48 gave NS with the ice-box specimens but only 28 gave like results with the natural urines transported by post.

All three types of samples from the 65 urines, after examination on receipt, were left at room temperature for a further three days and again examined. The second set of results is given in Table V. Fifty of the boric acid outfits gave NS results as against 39 ex-ice-box specimens and seven only of the natural urine samples. The outstanding feature of the comparisons of results "on receipt" and "after three days at room temperature" is surely the consistency of results with the boric acid outfit. It must be noted, however, that boric-acidpreserved urines may give misleading results if the delays in delivery are in excess of three days. This depends, in part at least, on the micro-organism present and is discussed later.

TABLE V.-Boric Acid Outfit Compared with Ice-box Urine and Natural Urine After Three Days on Bench at Room Temperature (18 C.)

\begin{tabular}{|c|c|c|c|c|c|c|c|c|}
\hline $\begin{array}{c}\text { Boric Acid } \\
\text { Outfit }\end{array}$ & & Total & $\begin{array}{c}\text { Ice-box } \\
\text { Urine }\end{array}$ & & Total & $\begin{array}{l}\text { Natural } \\
\text { Urine }\end{array}$ & & Total \\
\hline$s$ & .. & 9* & $S$ & $\ldots$ & 9 & SS & 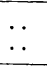 & $\begin{array}{l}8 \\
1+\end{array}$ \\
\hline DS & . & $6 \ddagger$ & $\begin{array}{l}\text { DS } \\
\mathrm{S}\end{array}$ & $\begin{array}{l}\cdots \\
\cdots\end{array}$ & $\begin{array}{l}4 \\
2\end{array}$ & DS & $\therefore$ & $\frac{1}{5}$ \\
\hline NS & $\ldots$ & 50 & $\begin{array}{l}\text { NS } \\
\text { DS } \\
\text { S }\end{array}$ & $\begin{array}{l}\ldots \\
\cdots\end{array}$ & $\begin{array}{r}39 \\
4 \\
7\end{array}$ & $\begin{array}{l}\text { NS } \\
\text { DS } \\
\text { S }\end{array}$ & $\begin{array}{l}\cdots \\
\cdots\end{array}$ & $\begin{array}{r}6 \\
2 \\
42\end{array}$ \\
\hline Total & . & 65 & Total & .. & 65 & Total & . & 65 \\
\hline
\end{tabular}

* 1 specimen, 5 days old-that is, 2 before receipt-was S,S,S in Table IV is now DS, S, S.

$t$ Final $p H$ 9 , after three days on bench.

$\neq 1$ specimen, 4 days old-that is, 1 before receipt-was DS, S, S in Table IV, is
now NS, S, S. 


\section{Comparisons of Boric-acid Preserved Urines and Natural Urine Samples from a General Practice}

All field trials up to now had involved patients in hospital. The final trial undertaken, and now reported, was possible through the co-operation of the doctors in a general practice on the mainland 42 miles $(67.5 \mathrm{~km}$.) distant from the laboratory. All samples were transmitted by post, with an average delay of one day. The trial involved two samples from each midstream specimen of urine, one in the boric acid outfit and the other a natural urine specimen, both packed and posted in the same envelope.

In all, 130 urines were so sampled. The results "on receipt" and also "after three days at room temperature" are given in Table VI. The results of the boric acid outfits on receipt were $18 \mathrm{~S}, 7 \mathrm{DS}$, and $105 \mathrm{NS}$. These results remained unaltered when the examinations were repeated on the same specimens after these had been allowed to stand for three days on the laboratory bench at a room temperature of around $18^{\circ} \mathrm{C}$. In contrast, the results of the natural urines on receipt were $40 \mathrm{~S}, 9 \mathrm{DS}$, and $81 \mathrm{NS}$. Moreover, when these natural urines were again examined after the same period of three days on the bench, the results were $93 \mathrm{~S}, 8 \mathrm{DS}$, and only 29 NS.

TABLE VI.-Comparison of Boric Acid Outfits and Natural Urine Samples from General Practice on Receipt and After Three Days on Bench

\begin{tabular}{|c|c|c|c|c|c|c|c|c|c|c|c|}
\hline \multicolumn{6}{|c|}{ On Receipt } & \multicolumn{6}{|c|}{ After 3 Days on Bench } \\
\hline $\begin{array}{c}\text { Boric } \\
\text { Acid } \\
\text { Outfit }\end{array}$ & & Total & $\begin{array}{l}\text { Natural } \\
\text { Urine }\end{array}$ & & Total & $\begin{array}{l}\text { Boric } \\
\text { Acid } \\
\text { Outfit }\end{array}$ & & Total & $\begin{array}{l}\text { Natural } \\
\text { Urine }\end{array}$ & & Total \\
\hline $\mathrm{S}$ & $\ldots$ & 18 & $S$ & $\ldots$ & 18 & $\mathrm{~S}$ & .. & 18 & $S$ & .. & 18 \\
\hline $\begin{array}{l}\text { DS } \\
\text { DS }\end{array}$ & $\therefore$ & $\begin{array}{l}2 \\
5\end{array}$ & $\underset{\mathrm{S}}{\mathrm{DS}}$ & $\begin{array}{l}. \\
.\end{array}$ & $\begin{array}{l}2 \\
5\end{array}$ & $\begin{array}{l}\text { DS } \\
\text { DS }\end{array}$ & .. & $\begin{array}{l}2 \\
5\end{array}$ & $\stackrel{S}{S}$ & . & $\begin{array}{l}2 \\
5\end{array}$ \\
\hline $\begin{array}{l}\text { NS } \\
\text { NS } \\
\text { NS } \\
\text { NS }\end{array}$ & $\begin{array}{l}\cdots \\
\cdots \\
\cdots \\
\cdots\end{array}$ & $\begin{array}{r}29 \\
8 \\
7 \\
44 \\
17 \\
\end{array}$ & $\begin{array}{l}\text { NS } \\
\text { NS } \\
\text { DS } \\
\text { NS } \\
\text { S }\end{array}$ & $\begin{array}{l}. \\
\because \\
\cdots \\
.\end{array}$ & $\begin{array}{r}29 \\
8 \\
7 \\
44 \\
17 \\
\end{array}$ & $\begin{array}{l}\text { NS } \\
\text { NS } \\
\text { NS } \\
\text { NS } \\
\text { NS }\end{array}$ & $\begin{array}{l}. \\
\because \\
\cdots \\
.\end{array}$ & $\begin{array}{r}29 \\
8 \\
7 \\
44 \\
17 \\
\end{array}$ & $\begin{array}{l}\text { NS } \\
\text { DS } \\
S \\
S \\
S \\
\end{array}$ & $\begin{array}{l}. \\
\because \\
\cdots \\
.\end{array}$ & $\begin{array}{r}29 \\
8 \\
7 \\
44 \\
17 \\
\end{array}$ \\
\hline $\begin{array}{l}\text { Totals: } \\
\text { S } \\
\text { DS } \\
\text { NS }\end{array}$ & $\begin{array}{l} \\
\cdots \\
\cdots\end{array}$ & $\begin{array}{r}18 \\
7 \\
105\end{array}$ & $\begin{array}{l}\text { S } \\
\text { DS }\end{array}$ & $\begin{array}{l}\because \\
\cdots\end{array}$ & $\begin{array}{r}40 \\
9 \\
81\end{array}$ & $\begin{array}{l}\text { S } \\
\text { DS } \\
\text { NS }\end{array}$ & $\begin{array}{l}\because \\
\because \\
\end{array}$ & $\begin{array}{r}18 \\
7 \\
105\end{array}$ & $\begin{array}{l}\text { S } \\
\text { DS } \\
\text { NS }\end{array}$ & $\because$. & $\begin{array}{r}93 \\
8 \\
29\end{array}$ \\
\hline
\end{tabular}

\section{Discussion}

Before it was decided to undertake field trials of boric acid in urine, experiments were carried out in the laboratory to assess the effects of adding different concentrations of the boric acid to routine urines after receipt. Altogether 168 urines were investigated. The optimal concentration of boric acid was found to be $1.8 \%$, which for routine purposes and preparation of outfits is equivalent to $0.5 \mathrm{~g}$. of powdered boric acid per 1-fl. oz. (28-ml.) universal bottle. This concentration prevents multiplication of micro-organisms present. For best results the exposure should not exceed four days.

Throughout the tests the micro-organisms encountered were species of Escherichia, Proteus, Klebsiclla, Pseudomonas, Streptococcus, Staphylococcus, and Candida. Only with an occasional strain of Proteus and Klebsiella did the boric acid seem to produce some reduction in numbers.

Trouble also arose with a few D.I.T.M. samples where Proteus spp. were present. Here confluent growths were obtained despite the use of electrolyte-deficient medium. This meant that an $S$ result had to be accepted when a lower result on the same urine was credited to the boric acid outfit (Table II). This same discrepancy is also to be noted in Table I, where three natural urines gave DS results as against $S$ with the D.I.T.M. and Proteus spp. were present. No explanation can be offered for the one specimen of urine which contained a Klebsiella sp. and gave DS with the D.I.T.M., NS with the boric acid outfit, and $S$ with the natural urine (Table II).

As well as maintaining the number of organisms present in each urine sample, the boric acid was shown by day-to-day observations to have no adverse effect on the content of albumin and sugar. Moreover, the numbers of red and white blood corpuscles and casts appeared also to suffer no appreciable diminution. It was demonstrated during these investigations that natural urines, which became markedly alkaline-for example, $p \mathrm{H}$ 9-on standing, showed a diminution from profuse to scanty pus cells. Boric acid keeps the urine $p H$ on the acid side of neutrality and so prevents dissolution of pus cells. This is important, since differentiation between urinary infection and bacilluria depends on the pus cell content.

One possible hazard of the boric acid outfit may occur at the hands of the user. The powder may be emptied out before the addition of urine, despite instructions to the contrary on the outfit label. Another source of trouble may occur if the bottle is not filled to the shoulder. The presence or absence of boric acid in the specimen can easily be confirmed by placing a drop of the urine on a strip of turmeric acid paper. Failure to produce the characteristic salmon-pink colour indicates absence of boric acid. At the discretion of the laboratory, such a urine may be examined as a natural urine, but when reporting the findings attention must be drawn to the age of the specimen on receipt and the absence of the preservative.

The use of boric acid as a preservative for laboratory specimens is not new. Baker (1925) indicated that a concentration of boric acid between 0.2 and $1 \%$ is effective in controlling contamination of fowls' blood sent by poultry-keepers to the laboratory for antibody levels in infections due to Salmonella pullorum. Boric acid ( $1 \%$ ) has been advocated by Traum and Henry (1930) for the preservation of milk naturally infected with Brucella abortus. This recommendation was based on a previous report by Traum and Hart (1916), who found that tubercle bacilli are not destroyed in milk preserved with $1 \%$ boric acid and that such preservation is sufficient to allow milk to be shipped long distances during the warm weather without undergoing changes that interfere with satisfactory laboratory examinations and inoculations in guinea-pigs. Boric acid has also been recommended for the preservation of urine before certain chemical analyses where the results may be vitiated by bacterial putrefaction (Heitzmann, 1928 ; Kolmer, 1944 ; Todd and Sanford, 1948).

No reference in the literature available has been found recommending the use of boric acid to preserve in transit urines for bacteriological examination. The present findings would suggest that $1.8 \%$ boric acid serves this purpose and has the added advantage of acting in like manner with regard to the content of albumin, sugar, red and white blood corpuscles, and casts. The addition of the boric acid to the 1-fl. oz. (28-ml.) universal container increases the cost by only 0.07 pence per outfit.

We wish to thank Mr. R. P. Cumming, New Gilbert Bain Hospital, Shetland, Dr. Sheila Konstam, Balfour Hospital, Orkney, and Drs. H. Nicol and R. M. Logan, Fraserburgh, for willing co-operation in the field trials. Thanks are also due to all laboratory personnel, especially W. Wood, senior technician, for careful attention to detail during the studies. Our thanks are due also to Mr. T. M. Clark for advice on boric acid and its detection.

\section{REFERENCES}

Baker, A. H. (1925). British fournal of Experimental Pathology, 6, 201. Heitzmann, L. (1928). In Urinary Analysis and Diagnosis, 5th rev. ed., edited by W. T. Dannreuther, p. 88. London, Baillière, Tindall and

Kass, E. H. (1956). Transactions of the Association of American Physi-

Kolmer, J. A. (1944). Clinical Diagnosis by Laboratory Examinations, 1 st rev. ed., p. 1004. New York, Appleton-Century.

Mackey, J. P., and Sandys, G. H. (1965). British Medical fournal, 2, 1286.

Naylor, G. R. E., and Guttmann, D. (1967). Fournal of Hygiene, 65, 367

Todd, J. C., and Sanford, A. H. (1948). Clinical Diagnosis by Laboratory Methods, 11th ed., p. 53. Philadelphia, Saunders.

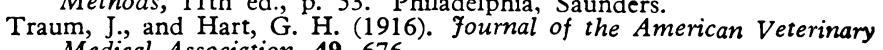
Medical Association, 49, 676.

Traum, J., and Henry, B. S. (1930). Fournal of Infectious Diseases, 47, 